\title{
PENGGUNAAN MODIF (MODEL PEMBELAJARAN BERVARIATIF) DAN MEDAN (MEDIA PEMBELAJARAN) DALAM PEMBELAJARAN PPKN
}

\author{
Nunung Fatimah \\ MTs Negeri 2 Karanganyar \\ E-mail: aifatimahnunung@gmail.com
}

\begin{abstract}
This study aims to analyze whether modif and medan can improve Civics learning outcomes class VII at MTs Negeri 2 Karanganyar. The method used was development research with a population of 315 students from 10 classes, with a random sample of 59 students. The results showed that the increase in Civics learning outcomes of students in the experimental class obtained a higher average pretest and psychological test compared to the control class, namely 80 and 65 and there was an implication on the increase in the value increase of pretest cycle I 79.3 (including good category) to 85.5 in the pretest cycle II and postest 95.9 cycle I to 98.6 (very good category) cycle II.
\end{abstract}

Keywords: MODIF; learning model; learning media; variative.

\section{ABSTRAK}

Penelitian ini bertujuan untuk menganalisis apakah modif dan medan dapat meningkatkan has il belajar PPPKN kelas VII di MTs Negeri 2 Karanganyar. Metode yang digunakan adalah penelitian pengembangan dengan populasi 315 siswa dari 10 kelas, dengan jumlah sampel 59 siswa secara acak. Hasil penelitian menunjukkan bahwa peningkatan hasil belajar PPPKN peserta didik pada kelas eksperimen memperoleh rata-rata pretest dan psikotes yang lebih tinggi dibandingkan dengan kelas kontrol yaitu 80 dan 65 dan adanya implikasi pada peningkatan peningkatan nilai dari pretest siklus I 79,3 (termasuk kategori baik) menjadi 85,5 di pretest siklus II dan postest 95,9 siklus I menjadi 98,6 (kategori sangat baik) siklus II

Kata kunci: MODIF; model pembelajaran; media pembelajaran; variatif.

\section{PENDAHULUAN}

Minat belajar berpengaruh terhadap hasil belajar, namun permasalahan yang sering terjadi adalah minat belajar siswa yang tidak sesuai dengan harapan (Aritonang, 2008); Nurutami dan Adman, 2016). Terutama minat terhadap pelajaran PPKN yang masih rendah. Pembelajaran PPKN seharusnya menggunakan berbagai model pembelajaran untuk mencapai tujuan pembelajaran sebagaimana yang dikemukakan Sutikno dalam Rahman
(2016) menyatakan, 'Model pembelajaran adalah cara penyajian materi yang dalam upaya untuk mencapai tujuan". Model pembelajaran yang digunakan yaitu model pembelajaran bervariatif, "Modif" seperti examples non examples, picture and picture, numberes heads together, cooperative script, STAD, Jigsaw, PBI, artikulasi, minp mapping, make a match, dan banyak lagi yang lainnya, jadi tidak hanya menggunakan satu model pembelajaran tapi harus menggunakan semua model pembelajaran yang ada

Cara mengutip: Fatimah, N. (2020). Penggunaan MODIF (Model Pembelajaran Bervariatif) dan MEDAN (Media Pembelajaran) dalam Pembelajaran PPKN. Inteligensi: Jurnal Ilmu Pendidikan, 3(2), 87-91 
sehingga bervariatif, Selain itu bisa juga menggunakan media pembelajaran (Medan), berupa media pembelajaran yang inovatif dan interaktif. Sehingga membuat anak merasa tertarik dalam mengikuti pembelajaran PPKN. Sehingga penulis membuat modif dan medan untuk mengatasi minat belajar terhadap PPKN.

Media pembelajaran harus menarik dan interaktif, sehingga dapat membentuk suasana belajar yang nyaman dan kondusif, untuk itu diperlukan multimedia interaktif di kelas (Candra, 2015), akan tetapi guru PPKN seringkali menggunakan metode ceramah jarang sekali menggunakan media pembelajaran ataupun model pembelajaran, disebabkan bukan hanya tidak menguasai teknologi tetapi juga bisa disebabkan karena malas. Jadi tidak hanya media pembelajaran yang menarik juga harus menggunakan model pembelajaran yang bervariatif seperti examples non examples, picture and picture, numberes heads together, cooperative script, STAD, Jigsaw, PBI, artikulasi, minp mapping, make a match, dan banyak lagi yang lainnya, jadi tidak hanya menggunakan satu model tapi harus menggunakan semua model pembelajaran yang ada sehingga bervariatif, maka guru harus kreatif dalam menggunakan modif tersebut dimasukkan kedalam materi yang ada.

Sementara Medan disini berarti mendukung modif, seperti membuat PPT, membuat video pembelajaran, gambar-gambar yang menarik siswa. Jadi Modif dan Medan saling berkaitan untuk membuat pembelajaran PPKN menjadi lebih menyenangkan, seperti membuat anak tertarik dan termotivasi untuk belajar PPKN serta tercapainya tujuan pembelajaran yang efektif dan efesien. Maka diperlukan penggunaan Modif (model pembelajaran bervariatif) dan Medan (media pembelajaran) dalam Pembelajaran PPKN". Dengan harapan tercapainya pembelajaran yang efektif dan efisien agar peserta didik pun lebih tertarik dan termotivasi dalam mengikuti pembelajaran PPKN serta mendapatkan hasil belajar yang optimal dan maksimal.

\section{METODE PENELITIAN}

Penelitian yang digunakan adalah pengembangan/ R\&D (Research and Development), yang digunakan untuk menghasilkan dan menguji produk agar lebih unggul, baru, efektif, efisien, produktif, dan bermakna (Sugiyono, 2012; Putra, 2013). Penggunaan modif (model pembelajaran variatif) dan medan (media pembelajaran) yang ada belum digunakan dalam pembelajaran PPKN untuk meningkatkan motivasi dan hasil belajar. Dengan melihat proses dan hasil belajar itu sendiri maka pembelajaran dapat dikatakan efektif, selain itu guru harus tahu kelemahan mereka sendiri melalui penilaian standar dan komprehensif metode pengajaran (Ilahi dan Imaniyati, 2016; Raisyifa dan Sutarni, 2016). Subjek penelitian uji coba produk terdiri atas 10 kelas VII MTs Negeri 2 Karanganyar,yang masing-masing kelas berisi 27 (kelas khusus) dan 32 (kelas reguler) dengan total 315 siswa. Sampel diperoleh secara acak yang berjumlah 59 siswa (19\%) dengan cara proporsional random sampling, yang dilanjutkan dengan kuasieksperimen dengan rancangan "PretestPosttest Control Group Design untuk 
mengetahui pengaruh penggunaan modif dan medan.

\section{HASIL DAN PEMBAHASAN}

Produk awal merupakan suatu produk yang dibuat untuk selanjutnya menghasilkan produk akhir dengan melalui beberapa tahap (Diamar \& Kuswanto, 2019). Penyusunan program pengembangan media pembelajaran sebagai tahap awal diawali dengan tahap perencanaan hingga pengembangan Modif dan medan. Pengembangan modif dan medan ini melalui beberapa tahapan diantaranya: (a) diawali dengan berbagai macam model pembelajaran bervariatif (modif) yang disesuaikan dengan materi PPKN yang diajarkan, diantaranya adalah examples non examples, picture and picture, numberes heads together, cooperative script, STAD, Jigsaw, PBI, artikulasi, minp mapping, make a match dan banyak lagi yang lainnya.; (b) selanjutnya dengan pengembangan medan (media pembelajaran) menggunakan PPT, flipbook dan media pembelajaran sway. Berikut merupakan contoh pengembangan media PPT yang disajikan pada gambar 1 berikut.
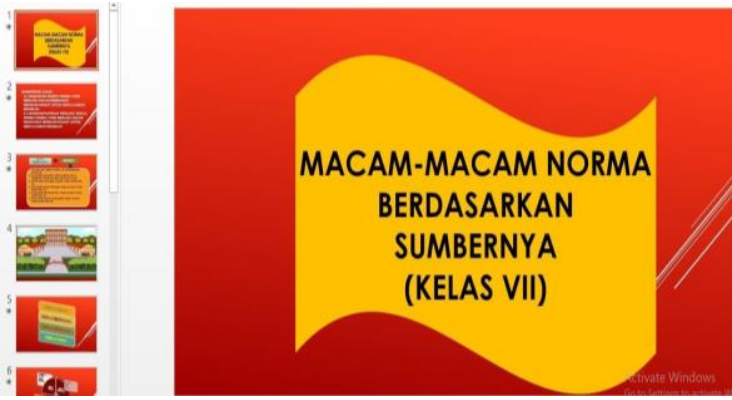

Gambar 1. Media PPT

Pengembangan media pembelajaran PPT mencantumkan tujuan pembelajaran, video nyanyian, bahan ajar berisi materi, dan gambar yang harus dianalisis. Selanjutnya mengembangkan media pembelajaran dengan menggunakan flipbook yang disajikan pada gambar 2 berikut.

\section{Gambar 2. Media Flipbook}

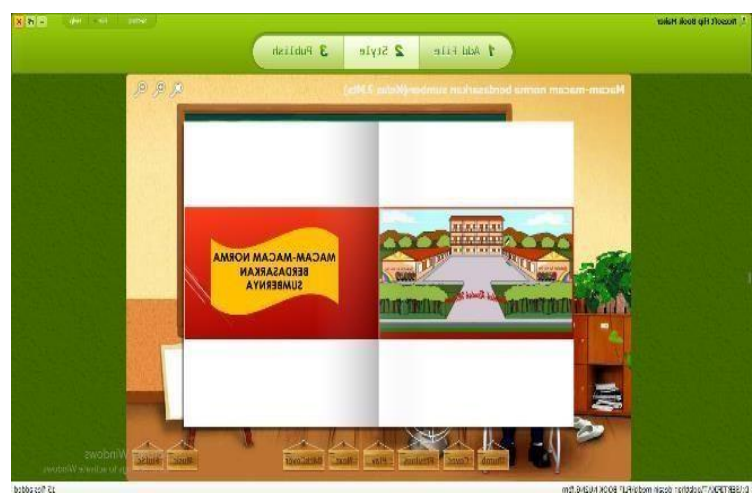

Media pembelajaran flipbook maker yang berbentuk buku, dimana didalamnya ada tujuan pembelajaran, gambar, video dan bahan ajar tentang materi.Selanjutnya adalah media pembelajaran dengan menggunakan microsoft sway, dimana ini dijalankan secara online, didalamnya ada video pembelajaran mengenai materi yang diajarkan. Berikut adalah contoh media sway disajikan pada gambar 3 berikut.

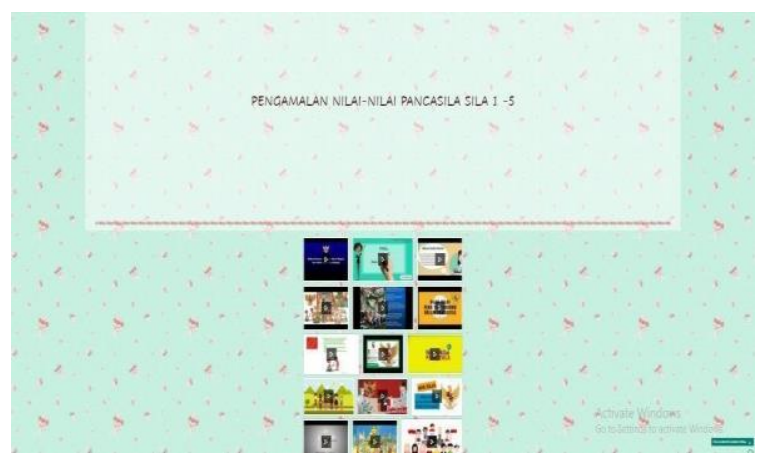

Gambar 3. Media Sway

Penggunaan modif dan medan sangat bermanfaat untuk peserta didik untuk meningkatkan semangat dan hasil belajar PPKN dibandingkan dengan penggunaan pembelajaran secara konvensional. Berdasarkan hasil, diperoleh nilai rata-rata pretest kelas eksperimen dan kontrol adalah 60 dan 44. 
Ini berarti dengan penggunaan modif dan medan hasil belajar pretest peserta didik lebih tinggi daripada menggunakan pembelajaran konvensional. Hal ini disebabkan dengan adanya modif dan medan anak tidak harus berusaha keras untuk belajar dirumah karena dikelas anak sudah mengingat memori tentang pembelajaran, sedangkan nilai rata-rata postest adalah 80 dan 65 . Serta dalam mengikuti pembelajaran siswa menjadi bersemangat karena diperlihatkan gambar dan video yang membuat mereka merasa tertarik dan menyenangkan. Uji prasyarat menunjukkan sampel berd is tribusi normal dan homogen. Uji hipotesis didapatkan thitung $=10,81$ yang menunjukkan bahwa thitung $>$ ttabel sehingga dapat disimpulkan terdapat pengaruh yang signifikan penggunaan modif dan medan terhadap hasil belajar siswa dengan pembanding pendekatan konvensional. Presentase hasil belajar siswa disajikan pada gambar grafik 4 berikut.

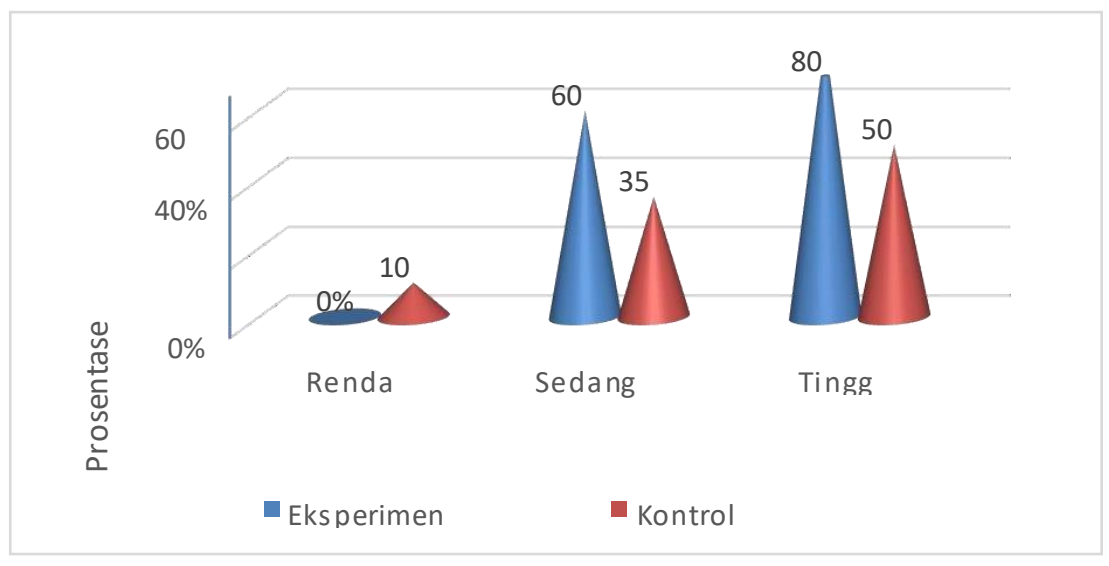

Gambar 4. Presentase Hasil Belajar Sis wa

Hasil belajar siswa kelas eksperimen berada pada kriteria rendah $0 \%$, sedang $60 \%$ dan tinggi $80 \%$, sedangkan kelas kontrol masing-masing $10 \%, 35 \%$, dam $50 \%$, sedangkan peningkatan hasil belajar secara klasikal pada kelas eksperimen sebesar 0,80 dengan kriteria tinggi. Perbedaan ini menunjukkan bahwa interaksi diantara siswa dan guru turuut berperan dalam menentukan hasil dan minat belajar siswa (Meilani \& Sutarni, 2016; Nurutami dan Adman, 2016). Uji-t juga menunjukkan thitung adalah 10,81 yang berarti terdapat pengaruh yang signifikan penggunaan modif dan medan terhadap peningkatan semangar dan hasil belajar siswa. Peningkatan tersebut juga menunjukkan bahwa penggunaan modif dan medan relatif lebih baik untuk meningkatkan semangat dan hasil belajar. Penggunaan modif dan medan dalam pembelajaran PPKN, mampu meningkatkan nilai dari pretest siklus 1 79,3 (termasuk kategori baik) menjadi 85,5 di pretest siklus 2 dan postest 95,9 siklus 1 menjadi 98,6 (kategori sangat baik) siklus 2 sehingga berimplikasi pada peningkatan semangat dan hasil belajar PPKN siswa, penggunaan modif dan medan juga berpengaruh terhadap semangat dan hasil belajar PPKN siswa kelas VII MTs Negeri 2 Karanganyar. Ini berarti terdapat pengaruh penggunaan modif dan medan dalam pembelajaran 
PPKN dalam meningkatkan semangat dan hasil belajar.

\section{SIMPULAN}

Penggunaan modif dan medan sangat berpengaruh terhadap peningkatan semangat dan hasil belajar peserta didik, dari yang dulunya anak menganggap bahwa pelajaran PPKN adalah pelajaran membosankan, dianggap remeh, nilainya juga tidak maksimal tapi dengan adanya penggunaan modif dan medan dalam pembelajaran PPKN membuat mereka bersemangat dan hasil belajarpun menjadi maksimal, dengan perolehan rata-rata kelas eksperimen lebih tinggi dibandingkan dengan kelas kontrol yaitu 80 dan 65 dan adanya implikasi pada peningkatan peningkatan nilai dari pretest siklus 1 79,3 (termasuk kategori baik) menjadi 85,5 di pretest siklus 2 dan postest 95,9 siklus 1 menjadi 98,6 (kate gori sangat baik).

\section{DAFTAR PUSTAKA}

Alif Aditya Candra, M. S. M. 2015. Pengembangan Multimedia Interaktif Dengan Pendekatan Saintifik Untuk Pembelajaran PPKN SMP Alif. 2(2), hal. 1-6. http://www.mendeley.com/research/ 6da0179a-e629-3c73-82eb$54439521 \mathrm{db} 61 /$.

Aritonang, K. T. 2008. Minat dan Motivasi dalam Meningkatkan Hasil Belajar Siswa," (10), hal. 11-21.

Ilahi, N. W. dan Imaniyati, N. 2016. Peran Guru Sebagai Manajer Dalam Meningkatkan Efektivitas Proses Pembelajaran," Jurnal Pendidikan Manajemen Perkantoran, 1(1), hal. 99. doi: 10.17509/jpm.v1il.3343.

Meilani, R. dan Sutarni, N. 2016. Penerapan Model Pembelajaran Cooperative Script Untuk
Meningkatkan Hasil Belajar,” Jurnal Pendidikan Manajemen Perkantoran, 1(1), hal. $176 . \quad$ doi: 10.17509/jpm.v1i1.3349.

Nurutami, R. dan Adman, A. 2016. Kompetensi Profesional Guru Sebagai Determinan Terhadap Minat Belajar Siswa," Jurnal Pendidikan Manajemen Perkantoran, 1(1), hal. 119. doi: 10.17509/jpm.v1il.3345.

Putra Diamar, Joko Kuswanto, J. O. 2019. Jurnal Bajet Pengembangan Media Pembelajaran Modul," 3(2), hal. 200-206.

Putra, Nusa. 2013. Research and Devolopment: Penelitian dan Pengembangan. Jakarta: Rajawali Pers.

Rahman, M. H. 2016. Pengaruh Model Pembelajaran Dan Gaya Mengajar Guru Tehadap Prestasi Belajar Siswa Pada Mata. 10(3), hal. 337-344.

Raisyifa, D. N. dan Sutarni, N. 2016. Pengaruh Kinerja Mengajar Guru Terhadap Motivasi Belajar Siswa," Jurnal Pendidikan Manajemen Perkantoran, 1(1), hal. 90. doi: 10.17509/jpm.v1il.3342.

Sugiyono. 2012. Metode Penelitian Pendidikan Kuantitatif, Kualitatif dan R\&D. Bandung: Alfabeta 